\title{
Application of Certainty Factor Method For Diagnosis Expert System Skin Diseases In Humans
}

\author{
Selvia Katarina Waruwu ${ }^{1}$, Agustina Simangunsong $^{2}$ \\ ${ }^{1.2}$ Informatics Engineering Study Program , STMIK Pelita Nusantara, J1. Iskandar Muda No. 1 \\ Medan, North Sumatra, Indonesia 20154 \\ E-mail: selviakatarinaw@gmail.com
}

Abstract-Dental disease is one of the many health problems Complained of by the people of Indonesia. Dental health is a reflection of human health. Lack of knowledge and limited sources of information on oral health have the caused public awareness to maintain oral and dental health is still low .. The development of one of the fields of information technology namely artificial intelligence has been Widely applied in various fields of life. In this study, the dental and oral disease expert system uses the Dempster Shafer method to control inferences that Contain thought patterns and reasoning mechanisms used by experts in solving problems.

Keywords: Dental, Expert System, the Certainty Factor

\section{Introduction}

Based on the knowledge and technological development in today's increasingly sophisticated and often called expert system. Then the skin disease patients can easily and quickly determine the type of skin disease based on symptoms experienced without investigation took so long.

The solution to this problem is to analyze, design and implement an expert system application that can perform skin disease diagnosis based on symptoms suffered.

\section{Theory}

\subsection{Understanding Expert System}

An expert system is a computer system that is intended to mimic all aspects (emulates) the ability of decision-making (decision making) an expert or knowledge that was loaded into an expert system. Expert systems optimally utilize specialized knowledge should an expert to solve the problem. Terms of expert systems (expert systems), often synonymous with knowledge-based systems (knowledge-based system) or knowledgebased expert systems (knowledge based expert systems) (Rossnelly, 2015:2)

\subsection{Certainty Factor Method}

One theory could be used to solve the problem of the uncertainty of certainty factor or CF is a value for the confidence measure introduced by a CF specialist in the manufacture Buchanan Shortliffe MYCIN expert system to indicate the magnitude of the trust. In Andriani (2017) CF indicate the size of the certainty of the fact or rule highest score in $\mathrm{CF}$ is certainly true +1.0 (Definitely not) and the lowest value in the CF is -1.0 definitely wrong, positive value represents a degree of confidence, while the value of negative represents the degree of uncertainty, certainty Factor defined as follows:

\section{CF $(\mathbf{H}, \mathbf{E})=\mathrm{MB}(\mathbf{H}, \mathrm{E})-\mathrm{MD}(\mathrm{H}, \mathrm{E})$}

Where :

$\mathrm{CF}(\mathrm{H}, \mathrm{E}) \quad=\quad$ factor certainty

$\operatorname{MB}(\mathrm{H}, \mathrm{E}) \quad=$ Size of trust / confidence level of the hypothesis $\mathrm{H}$, if

granted / influenced by evidence E (between 0 and 1)

$\operatorname{MD}(\mathrm{H}, \mathrm{E}) \quad=$ Size of distrust / disbelief level of the hypothesis H, if

\subsection{Skin} granted / influenced by evidence E (between 0 and 1)

Skin disease is a change in the skin that is caused by bacteria, parasites, viruses, fungi and infection that can hit from a variety of ages. This disease can also attack the whole or any part of the body concerned and can endanger the state of health of people with the disease if not treated quickly or serious. Due to several factors causing skin irritation is often the case, for example climate, unhealthy living habits, allergies, living environment is not clean, and so forth. Dyan Dyanmita daughter, M.Tanzil Furqan, and Rizal Setya Prime (2018). 
Journal of Computer Networks, Architecture and High Performance Computing e-ISSN 2655-9102, Volume 2, No. 2, July 2020, pp 191-194

3. Research methods

\subsection{Framework Research}

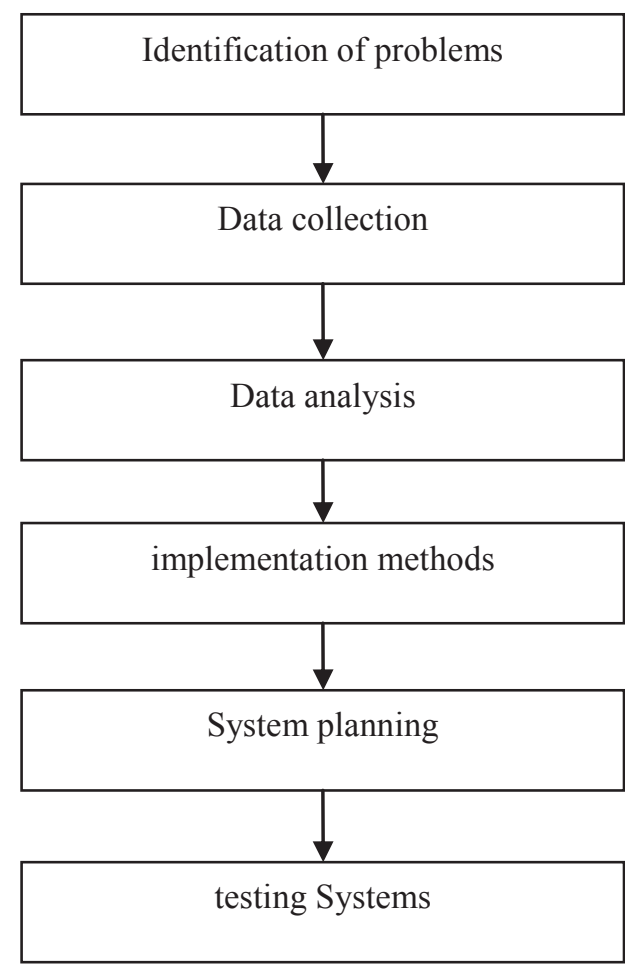

Picture 1. Research Framework

\section{Analysis and Design}

\subsection{Analysis}

The method used by the researchers in the study certainty factor system implementation methods for expert systems to diagnose skin diseases in humans are:

a. Interview

b. Study of literature

Table 1.

Skin Diseases Information

\begin{tabular}{clc}
\hline \multicolumn{2}{c}{ Disease } & $\begin{array}{c}\text { Code } \\
\text { Disease }\end{array}$ \\
\hline 1. & \multicolumn{1}{c}{ atopic eczema } & $\mathrm{P} 01$ \\
2. & contact eczema & $\mathrm{P} 02$ \\
3. & eczema seberoik & $\mathrm{P} 03$ \\
4. & Ringworm tinea pedlis & $\mathrm{P} 04$ \\
5. & Ringworm tinea cruris & $\mathrm{P} 05$ \\
6. & Ringworm tinea barbae & $\mathrm{P} 06$ \\
7. & nodular melanoma & $\mathrm{P} 07$ \\
8. & Melanoma lentino maligma & $\mathrm{P} 08$ \\
& HSV1 (simleks Herpes virus type & \\
9. & 1) & $\mathrm{P} 09$ \\
10. & HSV2 & $\mathrm{P} 10$ \\
11. & VZV (varicella-zoster virus) & $\mathrm{P} 11$ \\
12. & plaque psoriasis & $\mathrm{P} 12$ \\
13. & Scalp Psoriasis & $\mathrm{P} 13$ \\
14. & guttate psoriasis & $\mathrm{P} 14$ \\
\hline
\end{tabular}


Table 2.

Data Skin Disease Symptoms:

\begin{tabular}{cl}
\hline $\begin{array}{l}\text { Code } \\
\text { symptom }\end{array}$ & The names of Symptoms \\
\hline G01 & -Terasa itch \\
G02 & -Ruam crusty \\
G03 & -Ruam aqueous \\
G04 & -Red stain \\
G05 & -Bersisik skin \\
G06 & red -Ruam \\
G07 & -Timbul bump \\
G08 & -Lepuhan water \\
G09 & -Leather swell \\
G10 & -Bersisik yellowish \\
G11 & red -Leather \\
G12 & -Bersisik resembles a ring \\
G13 & Pink fringe \\
G14 & -Berwarna black / color resembling skin \\
G15 & -Kemunculan stains on the skin \\
G16 & -Terasa smarting \\
G17 & Color-change mole \\
G18 & -Hard to breathe \\
G19 & -Tahi broken and bloody flies \\
G20 & -Fever \\
G21 & -Muscle ache \\
G22 & -Limp \\
G23 & -Rasa burned / stabbed at the site of infection \\
G24 & -Timbul blisters that burst and dried up \\
G25 & -Sakit during urination \\
G26 & -Muncul ulceration \\
G27 & -Bintil skin \\
G28 & -Dry skin \\
G29 & -Problem affects nails \\
G30 & -Thick skin \\
G31 & -Leather chipped head \\
G32 & -HAIR temporary loss during deployment \\
G33 & -Bintik small red spots in the skin \\
G34 & -Onset sudden rash after illness / infection \\
\hline & \\
& \\
\hline
\end{tabular}

\section{Conclusion}

a. An expert system to diagnose skin disease in humans in this study is to analyze the data by using the method of Certainty Factor to determine the level of certainty of a disease eg Atopic eczema, Eczema contact, Eczema seberoik and others based on the data of symptoms such as rash watery, itchy and scaly skin which has been selected, then the data in the process, then the output is in the form of a solution based on the symptoms of the disease.

b. Applying the method of Certainty Factor in diagnosing skin diseases in humans by step method of Certainty Factor to enter the symptoms of the disease and the type of disease, input the MB dam MD, the establishment of the rule, the method perhitungsn Certainty Factor and output produce calculation results and diagnosis.

c. Designing and building an expert system that can be used to diagnose skin diseases in humans by implementing the method of Certainty Factor is by designing a Unified Modeling Language (UML) diantarnya usecase diagrams, activity diagrams, class diagrams and build systems using PHP and MySQL as the database,

\section{Reference}

[1] Dyan Dyanmita Princess., M.Tanjil Furqan "Classification of Skin Diseases In Humans decesion Method Using Binary Tree Support Vector Nachine (BDTSVM)". Development Journal of Information Technology and Computer Science Vol.2, No.5, May 2018, hlm.1912-1920.

[2] Fani Oktaviani., Alwiyah Mukaddas, "Profile of Drug Use Patients Dermatology Polyclinic Hospital Dermatology Anutapura Hammer". Galenika Journal of Pharmacy Vol. 2 (1): 38-42 March, 2016.

[3] Swara Yoga Ganda, "Software Engineering Web Based Theaters Ticket Booking". Vol. 4 No. October 2nd, 2016. 